\title{
Conjugated linoleic acid-induced milk fat reduction associated with depressed expression of lipogenic genes in lactating Holstein mammary glands
}

L.Q. Han ${ }^{1 *}$, K. Pang ${ }^{2 *}$, H.J. Li ${ }^{1 *}$, S.B. Zhu ${ }^{3}$, L.F. Wang ${ }^{1}$, Y.B. Wang ${ }^{1}$, G.Q. Yang ${ }^{1}$ and G.Y. Yang ${ }^{1,4}$

${ }^{1}$ College of Animal Science and Veterinary Medicine, Henan Agricultural University, Zhengzhou, China

${ }^{2}$ Xinyang Agricultural College, Animal Scientific Department, XinYang, China ${ }^{3}$ Agricultural and Forestry Science Institute of Zhengzhou, Zhengzhou, China ${ }^{4}$ Key Laboratory of Animal Biochemistry and Nutrition, Ministry of Agriculture, Zhengzhou, China

*These authors contributed equally to this study.

Corresponding authors: G.Q. Yang / G.Y. Yang

E-mail: mrswx@yahoo.cn

Genet. Mol. Res. 11 (4): 4754-4764 (2012)

Received January 5, 2012

Accepted May 28, 2012

Published September 17, 2012

DOI http://dx.doi.org/10.4238/2012.September.17.2

\begin{abstract}
The efficacy of conjugated linoleic acid (CLA) in diet supplements for milk fat reduction is well documented in several species. However, the mechanisms by which fatty acids regulate mammary lipogenesis remain largely unknown, especially with regard to gene expression of enzyme and regulators. In this study, 8 Holstein dairy cows in their mid-lactation period were randomly divided into 2 groups. Control cows received a Ca salt of palm oil fatty acid dietary supplement, and those in the CLA group were fed Ca salts of CLA (Ca-CLA), all in a dose of approximately $200 \mathrm{~g} \cdot \mathrm{cow}^{-1} \cdot \mathrm{day}^{-1}$ for 14 days. The milk yield was recorded daily, and protein, lactose, and fat in the milk were quantified every 3
\end{abstract}


days for 2 weeks. Fatty acids in the milk were analyzed with gas-liquid chromatography. Measurement of messenger RNA levels of the main lipogenic genes of lipoprotein lipase, acetyl-coenzyme $\mathrm{A}(\mathrm{CoA})$ carboxylase, fatty acid synthase, stearoyl-CoA desaturase, and transcription factors such as sterol response element binding protein 1 (SREBP1) and peroxisome proliferator-activated receptor $\gamma$ was performed in biopsy samples of mammary tissue on the last day. The results indicated that dietary Ca-CLA caused a continuous reduction of milk fat $(\mathrm{P}<0.01)$ with no effect on milk yield, milk protein, and lactose. The fatty acid profile in the milk from the CLA group differed from that from controls, and the yield of milk fatty acid decreased $(\mathrm{P}<0.01)$ with Ca-CLA supplementation. The depressed expression of lipogenic genes (lipoprotein lipase, acetyl-CoA carboxylase, fatty acid synthase, and stearoyl-CoA desaturase) demonstrated inhibition of fatty acid de novo synthesis and uptake in the mammary gland of the CLA group. Furthermore, the gene expression of transcription factor SREBP1 was also downregulated $(\mathrm{P}<0.01)$, but peroxisome proliferator-activated receptor $\gamma$ was unchanged, suggesting that SREBP1 may play a key role in the regulation of lipogenic gene expression in the lactating mammary gland.

Key words: Conjugated linoleic acid; Dairy cows; Gene expression; Milk fat synthesis; Sterol response element binding protein 1

\section{INTRODUCTION}

The intake of conjugated linoleic acid (CLA) and its positional and geometric isomers may benefit human health through biological processes including increased metabolism that can help treat obesity (Belury, 2002). Various ruminant-derived foods including milk and other dairy products contain CLA. In dairy cows, CLA is produced via biohydrogenation in the rumen and by the action of the enzyme $\Delta 9$-desaturase in mammary tissues (Griinari et al., 2000). In many studies, the addition of CLA has had a specific inhibitory effect on milk fat content (Bauman and Griinari, 2003). Abomasal (Chouinard et al., 1999; Baumgard et al., 2001) and intravenous (Viswanadha et al., 2003) infusion and dietary CLA supplementation (Giesy et al., 2002) reduce milk fat without affecting milk lactose, protein, or yield. A similar situation exists in diet-induced milk fat depression (MFD), a naturally occurring condition in which the reduction of milk fat is associated with the alteration of milk fatty acid profile (Bauman et al., 2008), supporting experimental observations.

Several mechanisms have been investigated in CLA-induced MFD, predominantly at the level of gene expression. In the lactating mammary glands of dairy cows, CLA decreases the expression of genes related to de novo fatty acid synthesis, desaturation, triacylglycerol formation, and transcriptional regulation (Baumgard et al., 2002; Gervais et al., 2009). Recently, much attention has been focused on transcription factors such as sterol response element binding protein 1 (SREBP1) and peroxisome proliferator-activated receptor $\gamma(\operatorname{PPAR} \gamma)$ in the regulation of milk fat synthesis (Bionaz and Loor, 2008). However, only a few publications (Harvatine and Bauman, 2006; Gervais et al., 2009) have reported the alternation of transcription factor gene expression in the mammary glands of lactating dairy cows with dietary CLA treatment. This study was designed to examine 8 dairy cows during mid-lactation to verify 
the effect of dietary supplement of the Ca salts of CLA (Ca-CLA) on milk fat content and fatty acid profile and to investigate whether this treatment would lead to the reduction of gene expression of lipogenic enzymes and regulators SREBP1 and PPAR $\gamma$ in the mammary gland.

\section{MATERIAL AND METHODS}

\section{Animals and diets}

Eight-year-old Holstein cows in mid-lactation from the Dairy Center of Henan Agricultural University were randomly selected into 2 four-animal groups assigned to a control or CLA. Cows at approximately $100 \pm 15$ days in milk received a Ca-protected fat supplement that was topdressed once daily on their concentrated diet. Cows in the control group received $200 \mathrm{~g} / \mathrm{day} \mathrm{Ca}$ salts of palm oil fatty acid, and cows in the CLA group received $200 \mathrm{~g}$ /day Ca-CLA (Zhongshan Unicare Natural Medicine Co., Ltd., China). The fatty acid composition of these supplements is shown in Table 1, and the composition and nutrient levels of the basal diet are shown in Table 2.

\begin{tabular}{lcr}
\multicolumn{2}{c}{ Table 1. Fatty acid composition of fat supplements $(\%)$} & Ca-CLA \\
\hline Fatty acids & Control & $<0.1$ \\
\hline C14:0 & 2.3 & 6.2 \\
C16:0 & 43.2 & 2.0 \\
C18:0 & 3.6 & 10.6 \\
C18:1 & 40.3 & 1.6 \\
C18:2 & 8.6 & 79.6 \\
CLA & - & 38.15 \\
Cis-9, trans-11 CLA & - & 36.85 \\
Trans-10, cis-12 CLA & - & 4.60 \\
Other CLA isomers & - & $<0.1$ \\
Others & 2.0 & \\
\hline CLA
\end{tabular}

CLA $=$ conjugated linoleic acid.

Table 2. Composition and nutrient levels of basal diet (DM basis) \%.

\begin{tabular}{lr}
\hline & Content \\
\hline Ingredients & \\
Corn & 28.00 \\
Soybean meal & 8.00 \\
Cottonseed meal & 10.00 \\
Wheat brain & 10.00 \\
Corn silage & 26.00 \\
Corn straw & 10.00 \\
Chinensis hay $_{\text {CaHPO }}^{3}$ & 4.50 \\
Limestone $_{\text {Premix* }}$ & 0.30 \\
Total & 1.20 \\
Nutrient levels & 2.00 \\
$\mathrm{NE}$ & 100.00 \\
$\mathrm{CP}$ & \\
$\mathrm{NDF}$ & 6.72 \\
$\mathrm{ADF}$ & 13.98 \\
$\mathrm{Ca}$ & 35.32 \\
$\mathrm{P}$ & 20.27 \\
\hline
\end{tabular}

*One kilogram of premix contains: $2000 \mathrm{mg} \mathrm{Fe}, 3000 \mathrm{mg} \mathrm{Cu}, 3000 \mathrm{mg} \mathrm{Mn,} \mathrm{12,100} \mathrm{mg} \mathrm{Zn,} 270 \mathrm{mg} \mathrm{I}, 60 \mathrm{mg} \mathrm{Co}$, $12 \mathrm{mg} \mathrm{Se}, 350,000 \mathrm{IU}$ VA, 60,000 IU VD, $2000 \mathrm{IU}$ VE, $450 \mathrm{~g} \mathrm{NaC1}_{3} \mathrm{NE}_{\mathrm{L}}$ is a calculated value, and the others are measured values. 


\section{Milk sampling}

Cows were milked three times daily, and each yield was recorded. Milk samples were collected every 3 days for analysis of milk fat, protein and lactose (Foss MilkoScan 4000 Instrument, Foss Electric). The final milk samples were harvested on day 14 and stored at $-80^{\circ} \mathrm{C}$ until the determination of fatty acid composition.

\section{Tissue biopsy}

Mammary gland biopsies were performed 4 to $5 \mathrm{~h}$ after the morning milking on day 14 of the treatment. Briefly, approximately $15 \mathrm{~min}$ before biopsy, cows received 30-40 mg intravenous xylazine and a subcutaneous injection of $20 \mathrm{~mL}$ lidocaine in a circular pattern surrounding the operation site. A 6-cm incision was made in the skin on the midpoint section of a rear quarter of the mammary gland. After the blunt separation of connective tissue, approximately $500 \mathrm{mg}$ sample from the exposed mammary tissue was biopsied, shaped, and rinsed with $0.9 \% \mathrm{NaCl}$ solution and frozen in liquid nitrogen. Samples were transferred to a freezer at $-80^{\circ} \mathrm{C}$ until further treatment.

\section{Fatty acid methyl ester (FAME) analysis}

Milk fat was extracted and subjected to FAME preparation with base-catalyzed transmethylation according to a protocol described by Chouinard et al. (1999). FAME were separated using an Agilent 6890 GLC (Agilent Technologies, Wilmington, DE, USA) equipped with a flame ionization detector and a $60-\mathrm{m} \times 0.32-\mathrm{mm}$ fused silica capillary column (DBFFAP, $0.25-\mu \mathrm{m}$ film thickness, Agilent). The $\mathrm{N}$ carrier gas pressure was constant, and the injector and detector temperatures were $250^{\circ} \mathrm{C}$. The initial oven temperature was $90^{\circ} \mathrm{C}$. After the injection of samples, the oven temperature was increased by $7^{\circ} \mathrm{C} / \mathrm{min}$ to $190^{\circ} \mathrm{C}$, increased by $3^{\circ} \mathrm{C} / \mathrm{min}$ to $215^{\circ} \mathrm{C}$, held for $10 \mathrm{~min}$, and increased by $20^{\circ} \mathrm{C} / \mathrm{min}$ to $230^{\circ} \mathrm{C}$ and held again for $5 \mathrm{~min}$. Fatty acid peaks were recorded and integrated using the GC ChemStation software (version A.09.03, Agilent). Individual fatty acids were identified by comparing retention times with known FAME standards (Nu-Chek Prep, Inc., Elysian, MN, USA).

\section{Total RNA preparation and real-time polymerase chain reaction (PCR)}

Total RNA was extracted from mammary tissue using a Pure Yield ${ }^{\mathrm{TM}}$ RNA Midiprep System (Promega) according to manufacturer instructions. RNA integrity was assessed through electrophoretic analysis of $28 \mathrm{~S}$ and $18 \mathrm{~S}$ ribosomal RNA subunits. RNA quality and quantity were measured with a NanoDrop ND-1000 spectrophotometer (Thermo, USA). The average $\mathrm{A}_{260} / \mathrm{A}_{280}$ ratio was 2.0, and average $\mathrm{A}_{260} / \mathrm{A}_{230}$ was 2.11. Each complementary DNA was synthesized with M-MLV reverse transcriptase (Promega) using $2 \mu \mathrm{g}$ total RNA. Real-time PCR was performed in an Eppendorf Mastercyler Realplex instrument. The primer sequences and reaction efficiencies of the standard curve for the target genes are shown in Table S1. The relative messenger RNA (mRNA) expression levels of lipogenic genes were normalized by 3 housekeeping genes - eukaryotic translation initiation factor 3 , subunit K; ubiquitously expressed transcript, and mitochondrial ribosomal protein L39 - in real-time RTPCR assays (Kadegowda et al., 2009). To calculate the relative expression ratio of the target 
gene, we used the formula described by Pfaffl (2001) and Vandesompele et al. (2002), which included correction for PCR efficiency (E) and 3 reference genes (REF): Ratio $=\mathrm{E}_{\text {target }} \Delta \mathrm{Ct}$ target

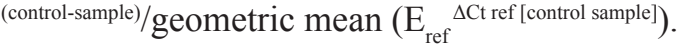

\section{Statistical analysis}

A mixed model using a generalized linear model with repeated measures (SPSS13.0, USA) was implemented to process the data from the treatment for milk yield and milk composition. The fixed factors included time and treatment. Fatty acid and mRNA expression values were analyzed with the two-tailed Student $t$-test.

\section{RESULTS}

\section{Milk yield and composition}

Milk yield averaged $40.4 \mathrm{~kg} /$ day (control) and $44.95 \mathrm{~kg} /$ day (CLA) without significant difference across treatments, suggesting that it was unaffected by the dietary addition of CLA. Milk fat content was remarkably decreased by $36 \%$ after Ca-CLA intake (Table 3). By contrast, milk protein and lactose content were unaffected. The temporal pattern of milk yield and protein and lactose content were nearly identical between the treatment and the control groups (Figure 1). The reduction in milk fat in the CLA group occurred by the first sampling on the first day of treatment and remained consistent throughout the 2-week period (see Figure 1).

Table 3. Composition of milk from lactating cows over 2 weeks of treatment*
\begin{tabular}{lcccr} 
& Control & CLA & SE & P \\
\hline Milk yield $(\mathrm{kg} /$ day) & 40.04 & 44.95 & 6.54 & 0.614 \\
Milk fat content $(\mathrm{g} / 100 \mathrm{~mL})$ & 3.49 & 2.21 & 0.21 & 0.16 \\
Milk protein content $(\mathrm{g} / 100 \mathrm{~mL})$ & 2.96 & 3.05 & 0.05 & 0.705 \\
Milk lactose content $(\mathrm{g} / 100 \mathrm{~mL})$ & 4.63 & 4.71 & 0.281 \\
\hline
\end{tabular}

* Cows received a dietary fat supplement consisting of Ca salts of palm oil fatty acids (control treatment) or Ca salts of a mixture of conjugated linoleic acid isomers (CLA treatment). Both treatments provided about $200 \mathrm{~g} / \mathrm{day}$ fatty acids.

\section{Milk fatty acid composition or profile}

Gas-liquid chromatography analysis of the FAME preparation revealed that the fatty acid composition of milk fat was markedly altered by Ca-CLA treatment (Table 4). Supplementing the diet with Ca-CLA significantly decreased the content of C6:0, C8:0, C10:0, and C16:0 and increased the content of $\mathrm{C} 18: 0, \mathrm{C} 18: 1$, and $\mathrm{C} 18: 2$ in cows consuming the milk fat compared with those consuming the control diet $(\mathrm{P}<0.05)$. No significant difference in the content of C4:0, C12:0, C14:0, C14:1, C15:0, or C16:1 in the milk fat of dairy cows was found between the CLA and control groups, although most of the fatty acids showed a trend of decrease in the CLA group. Of the CLA isomers in the milk fat, cis-9, trans-11 increased (P > $0.05)$ and trans-10, cis- 12 was undetectable. Supplementing the diet with Ca-CLA decreased the yield of total milk fatty acids, in which the summation of short- $(<\mathrm{C} 16: 0)$, medium- $(\mathrm{C} 16: 0$ $+\mathrm{C} 16: 1$ ), and long-chain fatty acids (C16) were significantly reduced (Figure 2). 

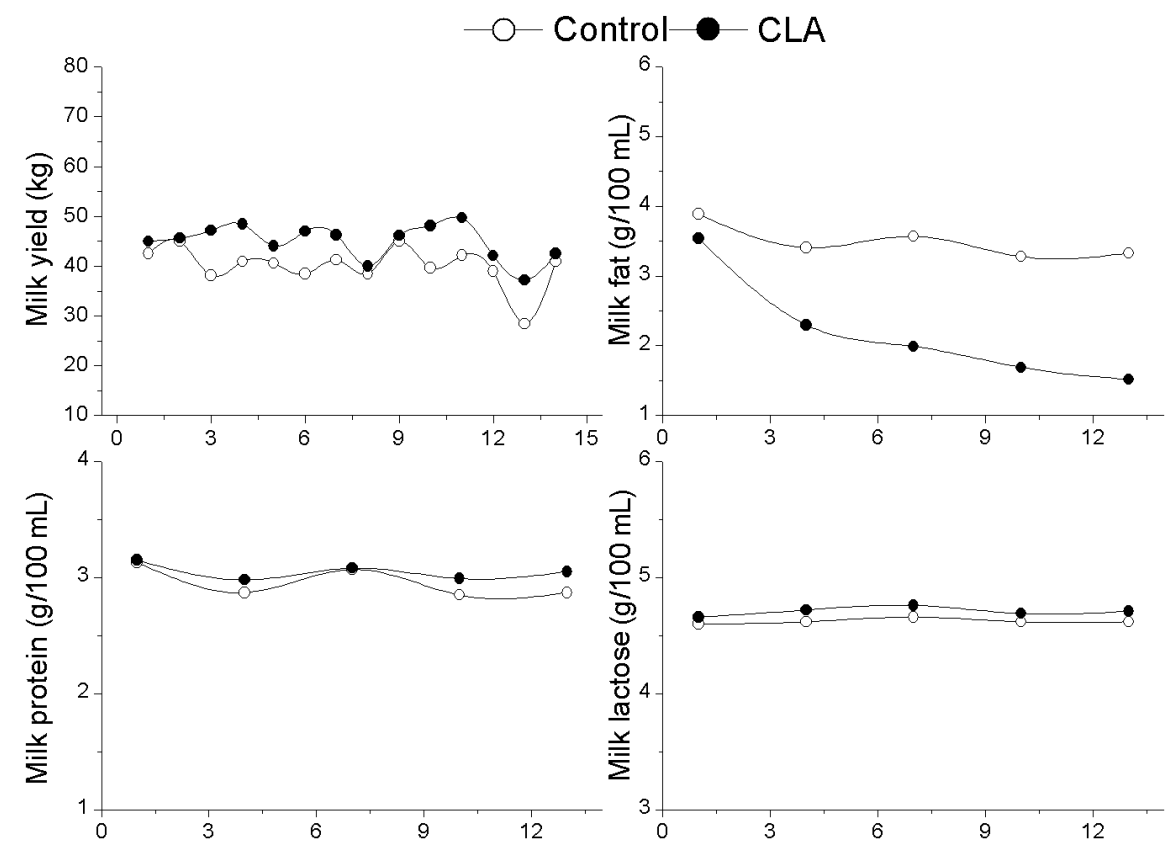

\section{Day of treatment}

Figure 1. Temporal pattern of milk yield (upper left), fat (upper right), protein (lower left), and lactose (lower right) content from lactating cows receiving a dietary fat supplement consisting of Ca salts of palm oil fatty acids (control) or Ca salts of a mixture of conjugated linoleic acid isomers (CLA). Values represent means from 4 cows over 2 weeks of treatment.

Table 4. Fatty acid composition of milk fat from lactating cows over 2 weeks of treatment $(\mathrm{g} / 100 \mathrm{~g})^{*}$.

\begin{tabular}{lccc}
\hline Fatty acids & Control & CLA & P \\
\hline C4:0 & $1.20 \pm 0.20$ & $0.88 \pm 0.36$ & 0.176 \\
C6:0 & $1.38 \pm 0.19$ & $0.84 \pm 0.25$ & 0.014 \\
C8:0 & $0.92 \pm 0.15$ & $0.49 \pm 0.16$ & 0.008 \\
C10:0 & $2.07 \pm 0.44$ & $1.21 \pm 0.32$ & 0.021 \\
C12:0 & $2.48 \pm 0.46$ & $1.82 \pm 0.38$ & 0.071 \\
C14:0 & $9.86 \pm 1.15$ & $8.80 \pm 1.81$ & 0.365 \\
C14:1 & $0.93 \pm 0.27$ & $0.58 \pm 0.34$ & 0.163 \\
C15:0 & $1.14 \pm 0.13$ & $1.05 \pm 0.08$ & 0.298 \\
C16:0 & $30.65 \pm 1.41$ & $26.69 \pm 2.81$ & 0.045 \\
C16:1 & $1.74 \pm 0.30$ & $1.59 \pm 0.09$ & 0.381 \\
C17:0 & $0.65 \pm 0.07$ & $0.68 \pm 0.09$ & 0.646 \\
C18:0 & $12.26 \pm 1.78$ & $17.25 \pm 2.58$ & 0.019 \\
C18:1 & $28.22 \pm 3.42$ & $29.27 \pm 2.73$ & 0.049 \\
C18:2 & $4.29 \pm 0.25$ & $5.52 \pm 0.45$ & 0.003 \\
Cis-9, trans-11 CLA & $1.07 \pm 0.15$ & $1.27 \pm 0.19$ & 0.150 \\
Trans-10, cis-12 CLA & $<0.01$ & $<.01$ & - \\
C20:0 & $0.29 \pm 0.03$ & $0.27 \pm 0.04$ & 0.855 \\
\hline
\end{tabular}

*Cows receiving a dietary fat supplement consisting of Ca salts of palm oil fatty acids (control treatment) or Ca salts of a mixture of conjugated linoleic acid isomers (CLA treatment). Both treatments provided about $200 \mathrm{~g} / \mathrm{day}$ fatty acids. (-) data not available. 


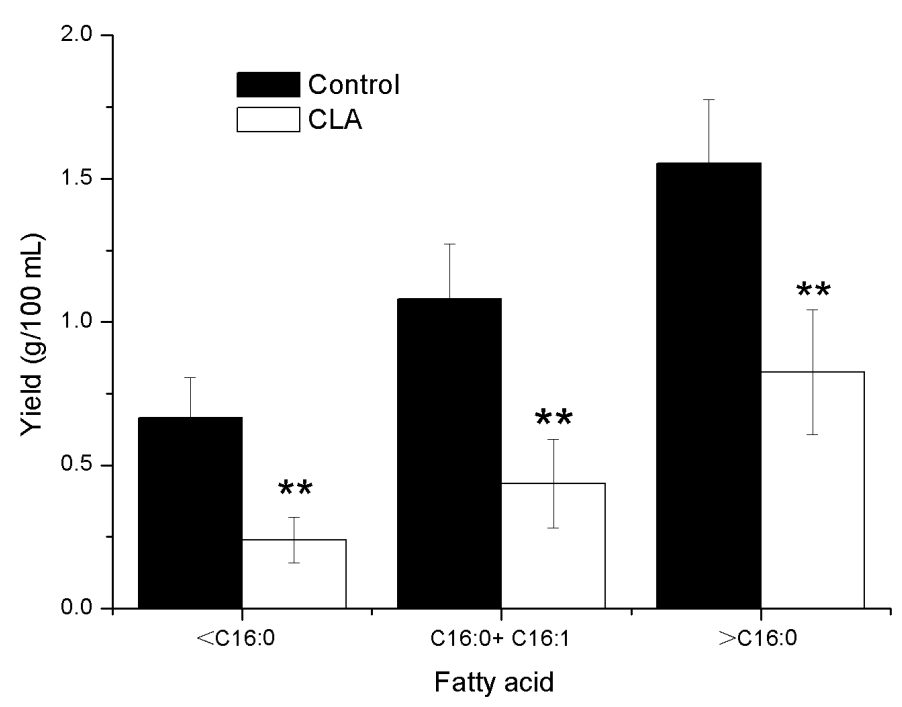

Figure 2. Milk fatty acid yield from lactating cows receiving a dietary fat supplement consisting of Ca salts of palm oil fatty acids (control) or Ca salts of a mixture of conjugated linoleic acid isomers (CLA). $<$ C16 represent fatty acids with short chains, $>\mathrm{C} 16$ with long chains, and $\mathrm{C} 16: 0+\mathrm{C} 16: 1$ with medium chains. Yield of fatty acids was calculated by multiplying milk fat mass with proportion of fatty acid. $* * \mathrm{P}<0.01$ for values representing means of 14 days of treatment.

\section{Lipogenic gene expression}

We examined the effect of dietary Ca-CLA treatment on mRNA abundance in mammary glands for several enzymes and regulatory factors with real-time PCR (Figure 3). Compared with that of the control, the expression of the lipogenic genes fatty acid synthase (FASN), acetyl-coenzyme A carboxylase (ACACA), and stearoyl-coenzyme A desaturase (SCD) in the CLA group was suppressed 0.47-, 0.30-, and 0.31-fold, respectively $(\mathrm{P}<0.01)$. In addition, the expression of lipoprotein lipase (LPL) $(\mathrm{P}<0.01)$, SREBP1 $(\mathrm{P}<0.01)$, and insulin-induced gene 1 (INSIG1; $\mathrm{P}<0.01$ ) was downregulated significantly, whereas the expression of PAPR $\gamma$ and PPAR $\gamma$ coactivator $1 \alpha$ (PPARGC1 $\alpha)$ was unchanged.

\section{DISCUSSION}

We administered dietary Ca-CLA to lactating dairy cows to reveal the effect of these fatty acids on milk fat formation. Because CLA can be metabolized by rumen biohydrogenation, we used Ca-CLA for dietary protection, which reduced the interaction of fats and microbial populations in the rumen (Giesy et al., 2002). We found that Ca-CLA did not alter milk yield, protein, or lactose content. Importantly, the addition of Ca-CLA to the diet effectively decreased fat yield (see Table 3 ) and a progressive reduction of this composition occurred during the treatment period (see Figure 1). Chouinard et al. (1999) have studied animals consuming diets supplemented with 50-100 g/day CLA, and Huang et al. (2008) have studied animals consuming diets supplemented with $150 \mathrm{~g} /$ day Ca-CLA and observed similar decreases in milk fat percentages. 


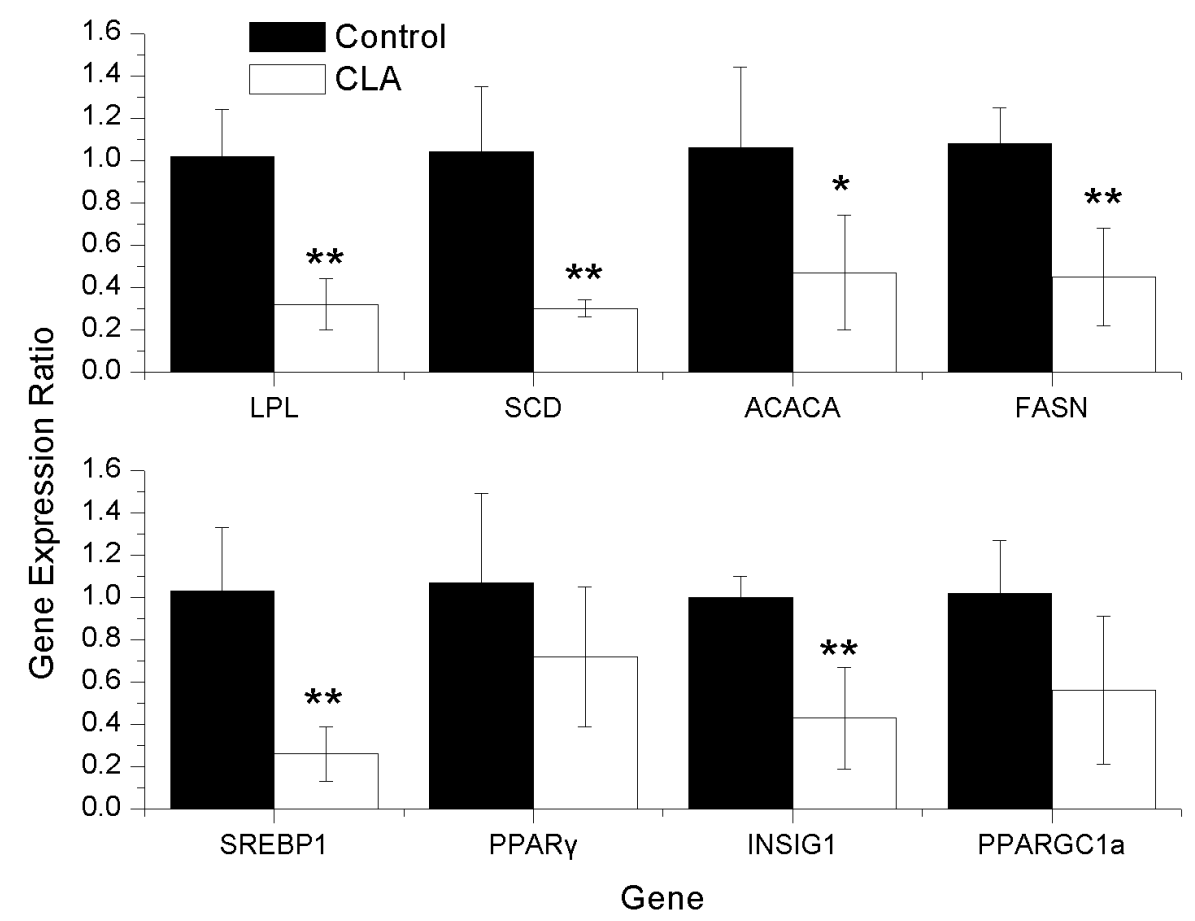

Figure 3. mRNA abundance of enzymes and regulators for milk fat synthesis from lactating cows receiving a dietary fat supplement consisting of Ca salts of palm oil fatty acids (control) or Ca salts of a mixture of conjugated linoleic acid isomers (CLA). $* \mathrm{P}<0.05$ and $* * \mathrm{P}<0.01$ for values representing means of 14 days of treatment. LPL $=$ lipoprotein lipase; $\mathrm{SCD}=$ stearoyl-coenzyme A desaturase; ACACA = acetyl-coenzyme A carboxylase; FASN $=$ fatty acid synthase; SREBP1 $=$ sterol response element binding protein $1 ;$ PPAR $\gamma=$ peroxisome proliferatoractivated receptor $\gamma$; INSIG1 $=$ insulin-induced gene 1; PPARGC1 $\alpha=\operatorname{PPAR} \gamma$ coactivator $1 \alpha$.

A number of theories have been proposed to explain diet-induced MFD. Bauman and Griinari (2003) have suggested that mammary fat synthesis is inhibited by specific trans-fatty acids as a result of alterations in rumen polyunsaturated fatty acid (PUFA) biohydrogenation. An important development supporting this theory was the discovery that MFD is associated with a specific increase in trans-10 C18:1. This finding was confirmed with a correlation of 0.84 between the increase in percentage of $\mathrm{C} 18: 1$ in milk fat and decreased milk fat yield (Loor et al., 2005). Although the GC analysis that we conducted did not allow for a separation of $\mathrm{C} 18: 1$ isomers, the increase we observed in total $\mathrm{C} 18: 1$ was consistent with the increase in trans-10 C18:1 reported by others. We also observed a significant increase in $\mathrm{C} 18: 1(\mathrm{P}<$ 0.05 ) in the fatty acid composition of milk caused by Ca-CLA supplementation. The other shifts in the fatty acid composition of milk, including decreased C4:0-C16:0 and increased C18:0,C18:2, are consistent with data reported by others (Chouinard et al.,1999; Giesy et al., 2002; Loor et al., 2005).

A curvilinear relationship between decreases in milk fat percentage and small increases in milk trans-10, cis-12 have been observed (Peterson et al., 2002). Duodenal infusion trials of pure CLA isomers have demonstrated that trans-10, cis-12 CLA inhibits milk fat synthesis, whereas the cis-9, trans-11 CLA isomer has no effect (Baumgard et al., 2000). However, in 
our GC analysis of the CLA isomers in milk fat, trans-10, cis-12 CLA was undetectable. The trans-10, cis-12 CLA levels are near zero in milk fat, and Perfield et al., (2002) have reported that the isomer of trans-10, cis-12 is undetectable in the milk fat of controls, but an increase is observed after a long treatment period with Ca-CLA.

The fatty acids in milk arise from 2 sources: uptake from circulation and de novo synthesis in mammary tissue (Bauman and Griinari, 2003). Short- and medium-chain fatty acids $(<\mathrm{C} 16)$ originate exclusively from de novo synthesis in the mammary gland, whereas long chain-fatty acids ( $>\mathrm{C} 16)$ are derived from uptake from the blood. CLA supplementation reduces the secretion of milk fatty acids of all chains in cows (Perfield et al., 2002) and sheep (Lock et al., 2006). In the present study, we showed a summarized reduction of short- and long-chain fatty acids during Ca-CLA treatment (see Figure 2). The mechanism for this inhibition appears to center on mammary metabolism and involve numerous mammary enzymes, including LPL, ACACA, FASN, and SCD. The ACACA and FASN enzymes are involved in de novo synthesis, whereas the LPL enzyme is involved in the uptake of plasma fatty acids. These fatty acids are desaturated by the SCD enzyme, resulting in the synthesis of cis-9 unsaturated fatty acid (Bernard et al., 2008). However, the molecular mechanism mediating the inhibitory effects is not well defined and requires the expression evaluation of lipogenic genes in the mammary glands of dairy cows.

The impact of PUFAs on lipogenic gene expression has been largely described in rodents (Kadegowda et al., 2010), whereas it is not well defined in lactating ruminants. The activity of ACACA and FASN in mammary tissue is reduced when lactating cows are fed an MFD diet (Piperova et al., 2000). Abomasal infusion of trans-10, cis-12 CLA was shown to decrease the mRNA abundance of LPL, ACACA, and SCD on Northern blot analysis (Baumgard et al., 2002), whereas infusion of CLA reduced the mRNA expression of ACACA, FASN, LPL, and SCD on real-time PCR with one reference gene (Gervais et al., 2009). We observed numeric reductions in the mRNA levels of lipogenic genes (LPL, ACACA, FASN, and SCD), and our data were more accurate and more reliable owing to analysis with real-time PCR using 3 appropriate reference genes for data normalization (Kadegowda et al., 2009). Taken together, these results demonstrated that the mechanism of milk fat depression with CLA supplementation involves the inhibition of de novo synthesis and uptake from circulation within the mammary tissue.

Recently a central role has been proposed for transcription factors as potent regulators of mammary lipid synthesis (Bionaz and Loor, 2008). The major transcription factors involved are SREBP1 and PPAR $\gamma$, which regulate the transcription of key enzymes in lipid synthesis. SREBP1 is synthesized as a precursor attached to the nuclear membrane and endoplasmic reticulum. After cleavage, the mature protein translocates to the nucleus and activates gene transcription. The genes of many lipogenic enzymes have SREBP1 response elements in their promoter, and Barber et al. (2003) have identified SREBP1 as a major regulator of de novo lipid synthesis through the activation of the ACACA PIII promoter in transfected HC11 mammary cells.

In rodents, PUFA downregulates the expression of SREBP1 via 2 mechanisms: inhibition of the proteolytic activation process of the SREBP1 protein and inhibition of SREBP1 gene transcription (Bernard et al., 2008). The abundance of SREBP1 mRNA and enzyme genes is reduced by the infusion of trans-10, cis-12 CLA in mammary tissue (Harvatine and Bauman, 2006; Gervais et al., 2009). We observed significant downregulation of the gene expression of SREBP1 and enzyme genes (LPL, ACACA, FASN, and SCD) associated with the uptake of Ca-CLA. These observations support the theory that CLA-induced milk fat decline 
occurs via a mechanism in which the inhibition event may happen upstream of the regulator of lipogenic gene expression.

Conversely, treatment of MAC-T cells with $75 \mathrm{M}$ trans-10, cis-12 CLA for $48 \mathrm{~h}$ reportedly does not affect the abundance of SREBP-1 mRNA but reduces the mature fragment of SREBP-1 protein (Peterson et al., 2004). The difference between in vivo and in vitro effects are not well understood, although Peterson et al. (2004) have suggested that longer-term treatment with trans-10, cis-12 CLA would lead to a reduced abundance of SREBP-1 mRNA.

INSIG1 plays an important role in the SREBP-mediated regulation of lipid biosynthesis by binding to the sterol-sensing domain of SREBP cleavage activating protein, and INSIG1 is responsible for the sterol-dependent retention of the SREBP cleavage activating protein/ SREBP complex in the endoplasmic reticulum (Yang et al., 2002). Little is known about the expression of the INSIG1 gene in the mammary glands of cows. In this study, the gene expression of INSIG1 was suppressed in mammary glands, shifting the signaling system of lipogenesis upstream of SREBP1, suggesting that SREBP1 and INSIG1 may play important roles in the regulation of lipogenic gene expression in the lactating mammary gland.

PPAR $\gamma$ belongs to a superfamily of hormone receptors that regulate the transcription of genes involved in various lipid metabolism pathways, including the transport of plasma triglycerides, fatty acid uptake, and peroxisomal $\beta$-oxidation (Bernard et al., 2008). PPAR $\gamma$ is known to bind and become activated by CLA in some tissues (Khan et al., 2003). PPARGC1 $\alpha$ interacts with PAPR $\gamma$, permitting the interaction of this protein with multiple transcription factors.

To our knowledge, this study is the first to report the expression of PPAR $\gamma$ in bovine mammary tissue during CLA treatment. However, we found no significant expression level of PPAR $\gamma$ and its coactivator PPARGC1 $\alpha$ in mammary tissue during CLA treatment. PPAR $\gamma$ mRNA abundance accounted for only $0.01 \%$ of the total lipogenic gene expression in bovine mammary glands (Bionaz and Loor, 2008). Bauman et al. (2008) have found no evidence of a role of PPAR $\gamma$ as a mechanism of CLA-induced MFD. Our results implied a limited role for PPAR $\gamma$ in the regulation of gene expression with CLA treatment.

In lactating dairy cows, dietary CLA supplementation resulted in continuous reduction of milk fat and downregulation of lipogenic gene expression. The transcription factor SREBP1 and its regulator INSIG1 contribute to the coordinated regulation of these lipogenic genes in the mammary gland.

\section{ACKNOWLEDGMENTS}

Research supported by the National Natural Science Fundation of China (\#31201869) and the National Sparking Plan Project of China (\#2011GA750001).

\section{Supplementary material}

\section{REFERENCES}

Barber MC, Vallance AJ, Kennedy HT and Travers MT (2003). Induction of transcripts derived from promoter III of the acetyl-CoA carboxylase-alpha gene in mammary gland is associated with recruitment of SREBP-1 to a region of the proximal promoter defined by a DNase I hypersensitive site. Biochem. J. 375: 489-501.

Bauman DE and Griinari JM (2003). Nutritional regulation of milk fat synthesis. Annu. Rev. Nutr. 23: 203-227.

Bauman DE, Perfield JW, Harvatine KJ and Baumgard LH (2008). Regulation of fat synthesis by conjugated linoleic acid: lactation and the ruminant model. J. Nutr. 138: 403-409. 
Baumgard LH, Corl BA, Dwyer DA, Saebo A, et al. (2000). Identification of the conjugated linoleic acid isomer that inhibits milk fat synthesis. Am. J. Physiol. Regul. Integr. Comp Physiol. 278: R179-R184.

Baumgard LH, Sangster JK and Bauman DE (2001). Milk fat synthesis in dairy cows is progressively reduced by increasing supplemental amounts of trans-10, cis-12 conjugated linoleic acid (CLA). J. Nutr. 131: 1764-1769.

Baumgard LH, Matitashvili E, Corl BA, Dwyer DA, et al. (2002). trans-10, cis-12 conjugated linoleic acid decreases lipogenic rates and expression of genes involved in milk lipid synthesis in dairy cows. J. Dairy Sci. 85: 2155-2163.

Belury MA (2002). Dietary conjugated linoleic acid in health: physiological effects and mechanisms of action. Annu. Rev. Nutr. 22: 505-531.

Bernard L, Leroux C and Chilliard Y (2008). Expression and nutritional regulation of lipogenic genes in the ruminant lactating mammary gland. Adv. Exp. Med. Biol. 606: 67-108.

Bionaz M and Loor JJ (2008). Gene networks driving bovine milk fat synthesis during the lactation cycle. BMC. Genomics 9: 366.

Chouinard PY, Corneau L, Barbano DM, Metzger LE, et al. (1999). Conjugated linoleic acids alter milk fatty acid composition and inhibit milk fat secretion in dairy cows. J Nutr. 129: 1579-1584.

Gervais R, McFadden JW, Lengi AJ, Corl BA, et al. (2009). Effects of intravenous infusion of trans-10, cis-12 18:2 on mammary lipid metabolism in lactating dairy cows. J. Dairy Sci. 92: 5167-5177.

Giesy JG, McGuire MA, Shafii B and Hanson TW (2002). Effect of dose of calcium salts of conjugated linoleic acid (CLA) on percentage and fatty acid content of milk fat in midlactation holstein cows. J. Dairy Sci. 85: 2023-2029.

Griinari JM, Corl BA, Lacy SH, Chouinard PY, et al. (2000). Conjugated linoleic acid is synthesized endogenously in lactating dairy cows by Delta(9)-desaturase. J. Nutr. 130: 2285-2291.

Harvatine KJ and Bauman DE (2006). SREBP1 and thyroid hormone responsive spot 14 (S14) are involved in the regulation of bovine mammary lipid synthesis during diet-induced milk fat depression and treatment with CLA. $J$. Nutr. 136: 2468-2474.

Huang Y, Schoonmaker JP, Bradford BJ and Beitz DC (2008). Response of milk fatty acid composition to dietary supplementation of soy oil, conjugated linoleic acid, or both. J. Dairy Sci. 91: 260-270.

Kadegowda AK, Bionaz M, Thering B, Piperova LS, et al. (2009). Identification of internal control genes for quantitative polymerase chain reaction in mammary tissue of lactating cows receiving lipid supplements. J. Dairy Sci. 92: 2007-2019.

Kadegowda AK, Connor EE, Teter BB, Sampugna J, et al. (2010). Dietary trans fatty acid isomers differ in their effects on mammary lipid metabolism as well as lipogenic gene expression in lactating mice. J. Nutr. 140: 919-924.

Khan SA and Vanden Heuvel JP (2003). Role of nuclear receptors in the regulation of gene expression by dietary fatty acids (review). J. Nutr. Biochem. 14: 554-567.

Lock AL, Teles BM, Perfield JW, Bauman DE, et al. (2006). A conjugated linoleic acid supplement containing trans-10, cis-12 reduces milk fat synthesis in lactating sheep. J. Dairy Sci. 89: 1525-1532.

Loor JJ, Ferlay A, Ollier A, Doreau M, et al. (2005). Relationship among trans and conjugated fatty acids and bovine milk fat yield due to dietary concentrate and linseed oil. J. Dairy Sci. 88: 726-740.

Perfield JW, Bernal-Santos G, Overton TR and Bauman DE (2002). Effects of dietary supplementation of rumen-protected conjugated linoleic acid in dairy cows during established lactation. J. Dairy Sci. 85: 2609-2617.

Peterson DG, Baumgard LH and Bauman DE (2002). Milk fat response to low doses of trans-10, cis-12 conjugated linoleic acid(CLA). J. Dairy Sci. 85: 1764-1766.

Peterson DG, Matitashvili EA and Bauman DE (2004). The inhibitory effect of trans-10, cis-12 CLA on lipid synthesis in bovine mammary epithelial cells involves reduced proteolytic activation of the transcription factor SREBP-1. $J$. Nutr. 134: 2523-2527.

Pfaffl MW (2001). A new mathematical model for relative quantification in real-time RT-PCR. Nucleic Acids Res. 29: e45.

Piperova LS, Teter BB, Bruckental I, Sampugna J, et al. (2000). Mammary lipogenic enzyme activity, trans fatty acids and conjugated linoleic acids are altered in lactating dairy cows fed a milk fat-depressing diet. J. Nutr. 130: 2568-2574.

Vandesompele J, De Preter K, Pattyn F, Poppe B, et al. (2002). Accurate normalization of real-time quantitative RT-PCR data by geometric averaging of multiple internal control genes. Genome Biol. 3: RESEARCH0034.

Viswanadha S, Giesy JG, Hanson TW and McGuire MA (2003). Dose response of milk fat to intravenous administration of the trans-10, cis-12 isomer of conjugated linoleic acid. J. Dairy Sci. 86: 3229-3236.

Yang T, Espenshade PJ, Wright ME, Yabe D, et al. (2002). Crucial step in cholesterol homeostasis: sterols promote binding of SCAP to INSIG-1, a membrane protein that facilitates retention of SREBPs in ER. Cell 110: 489-500. 